This is an electronic reprint of the original article. This reprint may differ from the original in pagination and typographic detail.

Please cite the original version: Tikanmäki I., Rathod P. (2019) Enhancing the Development of Interaction Between Authorities in Maritime Surveillance. In: Ntalianis K., Croitoru A. (eds) Applied Physics, System Science and Computers II. APSAC 2017. Lecture Notes in Electrical Engineering, vol 489. Springer, Cham, 207-214.

doi: $10.1007 / 978-3-319-75605-9 \_29$

URL: https://doi.org/10.1007/978-3-319-75605-9_29 


\title{
Enhancing the Development of Interaction between Authorities in Maritime Surveillance
}

\author{
Ilkka Tikanmäki and Paresh Rathod \\ Research, Development and Innovation, Laurea University of Applied Sciences, Vanha \\ maantie 9. FI-02650, Espoo, Finland \\ \{ilkka.tikanmaki@gmail.com\}\{paresh.rathod@laurea.fi\}
}

\begin{abstract}
Research study clearly indicates, there is a need for cooperation and information sharing between authorities and other Maritime related actors in security and safety issues on the European level. This study deals with European Common Information Sharing Environment (CISE) for the maritime domain. The purpose of this study was to enhance the development of authorities' interaction in maritime surveillance. The European testbed for the maritime Common Information Sharing Environment in the 2020 perspective (EUCISE 2020) and Finnish National Common Information Sharing Environment for Maritime Surveillance (FiNCISE) are also surveyed within this study. The research was conducted as a qualitative study and the research method is principally descriptive. The material of this paper consists mainly of the documents of the FiNCISE and EUCISE2020 projects, unclassified material of the Border Guard, and attending to and observing project meetings. In this research, it was found out, that during the FIMAC cooperation, maritime activities have been developed. As a result, organizations have become streamlined by combining overlapping systems and, thus, each operator is able to focus on its own core competence. Significant economic benefits have been achieved in technical surveillance and communication systems' constructing and maintenance of maritime traffic.
\end{abstract}

Keywords: Information Sharing; Authorities' Interaction; Cooperation; Maritime Surveillance; Maritime Safety; Common Information Sharing Environment.

\section{Introduction}

The cooperation between public authorities consists of common preparation, cooperation, sharing of information and coordination of activities. National cooperation between authorities is one way of maintaining a sufficient level of resources. Another way is cooperation between countries, which provides opportunities for the development of maritime cooperation. Joint Chiefs of StaffInterorganizational Cooperation report presents and argues that "Commitment to interorganizational cooperation can facilitate cooperation in areas of common interest, promote a common operational picture, and enable sharing of critical information and resources" [1]. The aim of the integrated maritime surveillance is to generate better 
situational awareness (SA) of activities on the maritime domain, and "Cross-sectorial interoperability for better Maritime Governance" [2]. According to [3] "The primary objective of the Union's Integrated Maritime Policy ('IMP') is to develop and implement integrated, coordinated coherent, transparent and sustainable decisionmaking in relation to the oceans, seas, coastal, insular and outermost regions and in the maritime sectors".

The European Border Surveillance System (EUROSUR) will establish an information sharing and cooperation mechanism that will enable Member State authorities to carry out border surveillance activities and the European Agency for the Management of Operational Cooperation at the External Borders of the Member States of the European Union (FRONTEX) to collaborate [4]. The EUROSUR development plan is to create a Roadmap for the Common Information Sharing Environment (CISE) for the EU maritime domain [5].

A Common Information Sharing Environment (CISE) will be developed together with the European Commission and thus, the Member States aim to integrate existing national maritime surveillance systems and networks [6]. Once completed, CISE will provide participating authorities needed access to information, and offering national and EU decision-makers' real-time situational information to process security events affecting their borders and security. There are seven user communities at the European Union level; (1) border control, (2) fisheries, (3) defence, (4) maritime safety and security, (5) marine environment, (6) customs, and (7) general law enforcement.

The research question of this study is: What processes will be needed for the efficient use of common information sharing environments on the European maritime domain?

\subsection{Methodology}

This study was conducted as a qualitative study and the research method is principally descriptive. This research focuses on the processes needed to efficiently use the Common Information Sharing Environment (CISE), which is being developed within the EU. Chapter 2 of this paper presents some known best practices examples of cooperation between authorities on the maritime domain, Chapter 3 is discussion on user processes and finally chapter 4 presents the conclusions of this study.

The collected source material for this study is based on participatory observations, conversations, scientific reports, collected articles, and literary reviews. The main strength of case study is this context is the ability to use many different sources of evidence to gain more information on issues than by using a single method [7]. The research problem has been evaluated through a constructive research approach [8]. This study uses an ethnographic method to collect data within phenomena. The most important ethnographic data collection method is the observation of participants, where the researcher is both an observer and a participant, and aims to gather information on human values and practices [9]. The main material of this paper consists of the documents of the EUCISE2020 and FiNCISE projects, unclassified material of the Border Guard, and attending to and observing project meetings. The 
study included co-operation between experts from different authorities and a researcher with the aim of utilizing practical experience.

\section{Cooperation between authorities on the maritime domain}

Interorganizational cooperation enables unity of effort, common objectives and common understanding [1]. [10] describes cooperation between authorities in his formal concept analysis as follows: "Cooperation between authorities is coordinated by the competent authority of cooperation between authorities and other obligated or authorized entities functioning together to achieve the goals of cooperation". The objectives of the co-operation are; (1) to increase situational awareness, (2) to share best practices, (3) to improve interoperability, (4) to avoid overlapping activities, and (5) to achieve focus and synergy by promoting cooperation.

Maritime Surveillance in the Northern Sea Basins (MARSUNO) was a pilot project to make existing monitoring and tracking systems more interoperable between the coastal Member States of Northern Europe. MARSUNO had six work groups that focused on: (1) Integrated Border Management and Law Enforcement IBM-LE), (2) Vessel Traffic Monitoring and Information Systems (VTMIS), (3) Maritime Pollution Response (MPR), (4) Search and Rescue (SAR), (5) Fisheries Control (FC), and (6) Maritime Situational Awareness MSA). The project's objective was to support Common Information Sharing Environment (CISE) by identifying practical solutions to cross-sector and cross-border information sharing between maritime authorities. [11].

\subsection{Finnish Maritime Authorities Co-operation}

The Finnish Maritime Authorities Co-operation (FIMAC) has been operating crosssector nationwide cooperation between authorities since 1994. FIMAC parties are the Finnish Transport Agency (FTA), the Finnish Transport Safety Agency (TRAFI), the Finnish Border Guard (FBG) and the Finnish Defence Forces (NAVY) [12]. Maritime surveillance sensor information is shared by TRAFI, FBG, NAVY, FTA and other relevant authorities as well as international actors. FIMAC cooperation goals are to increase maritime safety, to the development of information management and information exchange, international influence, and joint use of capabilities. Formatting of the national maritime situational picture (NMSP) and distributing it to cooperation partners is a significant mission of FIMAC [13].

Over 20 years of continued cooperation and efficiency in maritime activities have achieved savings merely in technical surveillance data communication systems investments, and maintenance expenditure [14]. In addition, each of FIMAC authority's specialists and equipment could be used for the common benefit. FIMAC actors have, in several aspects, implemented joint maritime surveillance, search and rescue (SAR), and maritime traffic control system with sensors, data transfer arrangement and applications. 


\subsection{Common Information Sharing Environment}

A Common Information Sharing Environment (CISE), which the European Commission is currently working to develop, together with the EU and EEA countries, will unite the different control systems and networks. With CISE the different authorities are going to get access to all the information necessary for maritime surveillance missions. The European Council adopted union-wide maritime security strategy on June 2014 [3]. One of the most important strategic goals is to create the integrated maritime policy for the EU to improve the exchange of information between the supervisory authorities of the sea. Further CISE development should direct to user demand and support operational user requirements [15].

The European Cooperation Project (Cooperation Project Maritime Surveillance, CoopP) aim was paving the way for smooth data transmission and easy access between public authorities. CoopP aimed to define the future Common Information Sharing Environment (CISE) for European maritime surveillance [15].

\subsection{EUCISE 2020}

A European testbed for the maritime Common Information Sharing Environment in the 2020 perspective (EUCISE 2020) addresses to steps forward along the accomplishment of the European roadmap for Common Information Sharing and Distributed Systems and Services Environment [16]. The project attains the widest possible experimental environment of innovative and collaborative services and processes between European maritime institutions. It also takes as reference a broad spectrum of factors in the field of European Integrated Maritime Surveillance, arising from the European legal framework, as well as from studies, pilot and related R\&D projects [17].

The integrated maritime surveillance's aim is to generate situational awareness (SA) activities at sea areas. CISE is a set of specifications for interoperability and it is based on the work of pilot projects Blue Maritime Surveillance System Mediterranean (BluemassMed), Maritime Surveillance in the Northern Sea Basin (MARSUNO) and of the Cooperation Project (CoopP). [15], [18].

EUCISE will reuse building blocks of Electronic Simple European Networked Services (eSens) and other previous projects that have developed European Digital Market through innovative ICT solutions [19]. One objective for EUCISE is to make a test-bed network of multiple nodes connected to participating authorities for crosssector information services and exchange of data [2].

\subsection{FiNCISE}

FIMAC -authorities and the Finnish Environment Institute (SYKE) launched a project, Study to promote Finnish National Common Information Sharing Environment for Maritime Surveillance (FiNCISE). The project aims to develop surveillance information systems in the Finnish sea areas. The project goals are to obtain developed systems to be compatible for the future maritime common 
information sharing environment (CISE) and to allow the exchange of information of national surveillance systems with other authorities through interfaces. FiNCISE supports directly the implementation of the European Maritime Security Strategy and its action plan [20]. The general objective of the FiNCISE project is to improve the interoperability of Finnish maritime surveillance systems nationally across sectors and cross-borders within EU. The focus is on system-to-system information exchange. One of the aims of the project is to develop a national enterprise architecture description related to the production and sharing of maritime surveillance information.

In addition, studies are carried out by developing data catalogue of existing national information service interfaces and data models. Comparing them to the CISE data model and defining the necessary changes will be studied as well. The exchange of national maritime information will be tested from a technical point of view with information service interfaces and data models at the national level and towards the CISE. FiNCISE focuses on designing of the information exchange and requirement development, as well as, takes into account current and future requirement [21].

The objectives of the FiNCISE project are 1) coordination of the Finnish maritime surveillance information exchange systems with the future CISE information exchange environment, and 2) to permit the exchange of information nationally through surveillance systems interfaces (FiNCISE, 2015). The project consists of four work packages (WP) which are: WP1 Project Management, WP2 Architecture descriptions, WP3 Interoperability and compatibility considerations, and WP4 Testing and demonstration.

Finland has a long history of sharing operatively maritime information among multiple governmental actors. As a result of this development, many systems are already implemented and used operationally nowadays. Full-scale system-to-system integration has not been implemented. However, FiNCISE project will lead actors to an enhanced level of interoperability. The project will develop primarily existing systems and information-sharing channels. The achievements of the project will be taken into action and the stakeholders will be benefitting the results in a sustainable way after the project has been successfully implemented [21].

The main Finnish national authorities with tasks or responsibilities for maritime safety functions are Border Guard, Defence Forces, Transport Safety Agency, Transport Agency, Finnish Environment Institute, Police, and Customs. At the legislative level, maritime security functions are provided for one authority's monitoring and implementing responsibility. However, particular functions have given to several authorities' responsibility while some functions are set to certain authority's control and entrusted to the other authority as participate in concept [22].

\section{Discussion}

First it is worth noting that cooperation between maritime authorities is a model that could be applied to the other areas of government. Yet, in many countries, national legislation does not allow the authorities to cooperate. There is a concern that the distributed information could end up to an operator, which is not desired to receive such information. The problem was seen particularly in the collection, analysis and 
lack of information sharing, which can be used in creating an effective maritime picture for the support of operational decision-making. [9].

The relevant information related to the decision-making is collected from different sources. This requires the exchange of information between different parties. The results of [23] research show that 'trust' can be said to be the main issue in multigovernment cooperation. As [23] state: "The exchange of information is always a matter of trust". According to [24], development of the cooperation activity requires a particular trust, continuity and shared vision of the rationality of action.

Cooperation must be part of the everyday activities and not only be based on cooperation exercises or treatment of exceptional situations. Authorities' activities will be intensified in the future. One of the most sensible ways is to find more effective interfaces to work and to combine the resources of those concerned. [25.]

\section{Conclusions}

The purpose of this study was to enhance the development of authorities' interaction in maritime surveillance, safety and security. The other aim of this study was to find out the good practices observed during the projects and to share them with other parties. In this research, it was found out, that during the FIMAC cooperation, maritime activities have been developed. As a result, organizations have become streamlined by combining overlapping systems and, thus, each operator is able to focus on its own core competence. Significant economic benefits have been achieved in technical surveillance and communication systems' constructing and maintenance of maritime traffic.

It is difficult to concretize all the savings brought by this operating model. The value of the common situational awareness (CSA) and trust cannot be measured by money; its high value appears at the level of activity almost every day. Close cooperation has facilitated negotiations on difficult issues even other than the FIMAC-operating matters. FIMAC cooperation model began as technical cooperation and is today a low-threshold approach that ensures the functioning of operational cooperation. Cooperation has become routine and a part of everyday life.

Therefore, the decision-makers should consider approving agreements that are needed to ensure a coordinated implementation of the information sharing. Authorities need to continue interconnecting systems, focusing on cross-border and cross-sector information services. Distributed architecture enables this kind of stakeholders' operating model.

International cooperation requires the creation of unified operating models. By harmonizing the practices and unifying operating models, national and international co-operation comes more efficiency; shipping will be safer, and systems become more efficient usage. Establishing trust among different CISE participants, CISE system can be improved by building a security policy by defining the minimal safety requirements that all CISE users and communities must comply with. The authorities stressed the main obstacle to the information exchange is differences in mind-sets. Fundamental aspects of cross-sector and cross-border information exchange are to amend the way of thinking and to build trust between authorities. 
CISE is important for the European Union and its security. EUCISE2020 project must take into account not only the project, but as a stepping stone for a common European data exchange environment, which will give added value to security and safety. The work needs to be transparent and it also has to be clearly led into because lack of information sharing between actors causes confusion. Maritime Security Strategy and the European Common Maritime Policy will provide a solid basis for this kind of work.

Acknowledgments. This project has received funding from the European Union's EMFF programme under grant agreement No EASME/EMFF/2014/1.2.1.2/5/SI2.715264. Study to promote Finnish National Common Information Sharing Environment for Maritime Surveillance (FiN-CISE).

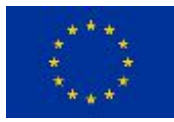

\section{References}

1. Joint Chiefs of Staff: Interorganizational Cooperation. Joint Publication 3-08. 2016, http://www.dtic.mil/doctrine/new_pubs/jp3_08.pdf. (2016).

2. EUCISE: EUCISE 2020 project meeting: "EUCISE2020, European testbed for the maritime Common Information Sharing Environment in the 2020 perspective". (2015)

3. European Commission: $\operatorname{COM}(2010) 584$ Final. Communication from the Commission to the Council and the European Parliament: on a Draft Roadmap towards establishing the Common Information Sharing Environment for the surveillance of the EU maritime domain. (2010).

4. Laitinen, I.: Key Note as Executive Director of FRONTEX, "Role of Border Control in the new EU security architecture and an update on Frontex activities", Situation Scope Seminar presentation, Äkäslompolo Finland on 11 March 2011. (2011).

5. European Commission: Directorate-General, Maritime Affairs and Fisheries, The development of the CISE for the surveillance of the EU maritime domain and the related Impact Assessment. Part 2: Combined Analysis, http://www.cowi.com. (2017).

6. European Commission: Security in 2020: Meeting the challenge. Luxembourg: Publications Office of the European Union, 2014. ISBN: 978-92-79-43762-5. (2014).

7. Yin, R.: Case Study Research. Design and Methods, London: SAGE Publications. (2009).

8. Lukka, K.: Constructive research: nature, process and evaluation. Transl. Konstruktiivinen tutkimusote: luonne, prosessi ja arviointi. In K. Rolin, M-L. Kakkuri-Knuuttila, and E. Henttonen (eds.). Applied social science and philosophy.. Helsinki: Hakapaino Oy. Pp 111133. (2006)

9. Vuorisalo, V.: Developing Future Crisis Management - An Ethnographic Journey into the Community and Practice of Multinational Experimentation. University of Tampere. Tampereen Yliopistopaino Oy - Juvenes Print: Tampere (2012)

10. Valtonen, V.: Collaboration of Security Actors - an Operational-Tactical Perspective, Transl. Turvallisuustoimijoiden yhteistyö - operatiivis- taktisesta näkökulmasta. The National Defence University. Dissertation. Helsinki: Edita Prima Oy (2010).

11. European Commission: COM (2012) 491 final. Report from the Commission to the European Parliament, the Council, the European Economic and social committee and the Committee of the regions; Progress of the EU's Integrated Maritime Policy. Brussels 11.9.2012 (2012) 
12. Finnish Maritime Authorities (FIMAC): Strategy 2013 (2013)

13. FiNCISE Monitoring visit. Helsinki 12.9.2016 (2016)

14. Finnish Defence Forces: Maritime activities are developed through co-operation, Transl. "Merellisiä toimintoja kehitetään yhteistyöllä", http://www.mil.fi (2014)

15. Finnish Border Guard: Test Project on cooperation in executing various maritime functionalities at sub-regional or sea-basin level in the field of integrated maritime surveillance (CoopP). Final Report, March 2014. Paris: Elan Graphic. ISBN: 978-952-491901- 2 (2014)

16. Council of the European Union: Council conclusions on integration of Maritime Surveillance: Towards the integration of maritime surveillance: A common information sharing environment for the EU maritime domain. 3092nd General Affairs Council meeting (2011)

17. European Commission: Communication from the Commission to the European Parliament and the Council, COM (2014) 451 final. Better situational awareness by enhanced cooperation across maritime surveillance authorities: next steps within the Common Information Sharing Environment for the EU maritime domain (2014)

18. BlueMassMed: Final Report: Cross-border and Cross-Sectoral Maritime Information Sharing for a control of activities at sea, http://www.statewatch.org/news/2014/jul/eu-2012bluemassmed-final-report.pdf, (2012)

19. e-SENS: e-SENS white paper; Short, Medium and Long-term Governance Models Scenario. Electronic Simple European Services, http://www.esens.eu, (2016)

20. European Union: Maritime Security Strategy, 11205/14 (2014)

21. Finnish Border Guard: FiNCISE application form to European Commission, European Agency for Small and Medium Enterprises (EASME), (2015)

22. Osola, K.: An Integrated Maritime Policy for the European Union - Horizontal maritime security missions, Transl. Euroopan Unionin yhdennetty meripolitiikka - monialaiset merelliset turvallisuustehtävät. Pro Gradu, The National Defence University (2012)

23. Rajamäki, J. and Knuuttila, J.: Cyber Security and Trust: Tools for Multi-agency Cooperation between Public Authorities. 7th International Joint Conference on Knowledge Discovery, Knowledge Engineering and Knowledge Management (KMIS 2015), pp. 397404, (2015)

24. Räsänen, T.: Complexity theoretical viewpoint of cooperation between the authorities, Transl. Kompleksisuusteoreettinen näkökulma viranomaisten yhteistoimintaan. Pro Gradu. National Defence University (2011)

25. Anttonen, J.: Building a common security. The possible synergies of developing the police and officer professions in tandem, Transl. Yhteistä turvallisuutta rakentaen - Poliisi- ja upseeriprofessioiden yhteiskehittelyn mahdollisuuksista. The National Defence University. Series 1: Research Publications No.6. Doctoral Dissertation. Juvenes Print: Tampere, (2016) 